\title{
Democracy and Water: hydrological spatial organization by recently democratized Regional Water Boards, a Dutch first?
}

\section{GERRIT ROT}

Soil Moisture Concern foundation/stichting BodemvochtBelang, Spreeuwenlaan 25, 1742GA Schagen, Netherlands g.rot@quicknet.nl

\section{Democracy and the IAHS Panta Rhei Programme}

The Panta Rhei programme emphasizes the importance of interaction between hydrology and society. The author strongly believes that this interaction can and will be intensified when the decision process concerning spatial organisation of land and water issues is totally democratized. Recent developments in the Netherlands could result in a truly and fully democratic spatial organisation decision process of combined water and land Development Plans, a decision model with probably much relevance for other democratic countries in the world.

\section{Democratization of Regional Water Boards in the Netherlands, safeguarded for the future?}

At the moment, the Netherlands has 12 Provinces, 24 Regional Water Boards and 403 Municipalities, the boundaries of which mostly do not coincide. Under the new Water Board Law of 2008, a party list system was introduced equivalent to municipality elections for a five year period. The law was nearly over-turned in 2012, but the government fell and new elections under the 2008 law were postponed until March 2015, at the same time as the Provincial elections. Most party lists consist of existing national parties or regional parties, but two national water parties were introduced with quite election success.

\section{Comparison of the effects of the 1983 democratization of the Land Reallocation Law of 1954}

The author has been a counter expert for the protection of nature and landscape in the two last reallocation projects of West-Friesia in the province of North-Holland. Thanks to the law change in 1983, it is not the farmers and Central Government that decide on reallocation projects but the Provinces: due to this approach the spatial organization became much more multi-disciplinary, protecting nature, the cultural history of the landscape and interests of tourism and recreation more fully, integrating them with agricultural and water board purposes. The same democratization is aimed for in future development plans.

\section{Climatic change and therefore needed landscape reinforcement hydrological projects}

In the governmental Deltaprogramma 2014 dealing most extensively with hydrological measures (Ministries of Infrastructure and of Economy) many small and larger Development Plans are proposed. Until now they were initiated by the National and Provincial governments and prepared by municipalities consulting the regional water boards, in conformity with the Law on Spatial Organization.

A new law on spatial organization is being developed between 2014 and 2016 (Omgevingswet). This law might result in Water Boards and Municipalities making development plans together under the guidance of the Provinces. Also the law on water board elections will be evaluated in 2015. The motivation to vote in Regional Water Board elections would be enhanced if, in the new law, Regional Water Boards become more equivalent to municipalities. It would also enhance public awareness of water problems, as advocated by the OECD 2014 study. Climatic resiliency of landscapes needs to be understood and supported by the general public.

The outcome of the future land decision procedures will be published in the nearby future.

\section{REFERENCES}

Ministerie van Infrastructuur en Milieu \& Ministerie van Economische Zaken (2013) Deltaprogramma 2014, Werk aan de Delta, kansrijke oplossingen vooropgaven en ambities.

OECD (2014) Water governance in the Netherlands: fit for the future? OECD Studies on Water 1-298. OECD Publishing. 